\title{
Relationship Between Warm Ischemic Time and Resistive Index on Creatinin Reduction Ratio Day Two After Living Kidney Donor Transplantation
}

\section{Lusito", Ayudyah Nurani', Dwi Lestari Partiningrum', Arwedi Arwanto', Lestariningsih', Shofa}

\author{
Chasani \\ 'Division of Nephrology and Hypertension, Department of Internal Medicine, Medical Faculty \\ Diponegoro University/Kariadi Hospital Semarang
}

Email korespondnsi: lusito179@gmail.com

\begin{abstract}
Background: Kidney transplantation (KT) may improve kidney function, via filtration, excretion, and hormonal function better than other kidney replacement therapies. Many factors may cause graft rejection or delayed graft function which may decrease the prognosis for graft survival. Objective: This study aims to determine associated factors of serum creatinine reduction ratio day 2 (CRR2) after living kidney donor transplants. Materials and Methods: This research used a retrospective cohort study design, with total sampling based on complete documents was done. A total 44 respondents (from 2012 to January 2020) and 22 respondents (based on the complete Resistive Index (RI) were recorded since 2018). Early Graft Function was defined using CRR2. Immediate Graft Function (IGF) was defined if CRR2 > 30\% and Delayed Graft Function (DGF) if CRR2 $\leq 30 \%$. Results: The results of Multiple logistic regression analysis from 44 samples showed that Warm Ischemic Time (WIT) $\leq 40$ minutes was significantly associated with IGF (OR 10.78; $95 \% \mathrm{Cl}: 1.66$ to $70.16 ; \mathrm{p}=0.01$ ). A result with 22 samples showed that, only $\mathrm{RI} \leq 0.7$ was significantly associated with IGF (OR 0.11; $95 \% \mathrm{Cl}$ : $0.03-0.41 ; \mathrm{p}=0.002)$. Conclusion: In conclusion, WIT and RI influence on EGF with parameters CRR2 of living-donors. KT Patients with WIT $\leq 40$ minutes and $\mathrm{RI} \leq 0.7$ had a higher risk of IGF.
\end{abstract}

Keywords: warm ischemic time, restrictive index, creatinine reduction ratio, immediate graft function, delayed graft function.

\section{PENDAHULUAN}

Hasil riskesdas 2018 menunjukan jumlah penderita Penyakit Ginjal Kronik usia $\geq 15$ tahun di Indonesia sebesar 3,8/1000 penduduk, dengan 19,3\% pernah atau sedang cuci darah. Data tersebut bila dibandingkan dengan hasil riskesdas tahun 2013 maka pada tahun 2018 terjadi peningatan angka kejadian Penyakit Ginjal Kronik sebesar 1,8/1000 (kemenkes RI, 2013). Tindakan transplantasi ginjal merupakan salah satu terapi yang dilakukan pada penanganan penyakit ginjal tahap akhir. Tindakan transplantasi ginjal di Indonesia sudah dilakukan sejak tahun 1977. Seiring 
dengan perkembangan teknologi maka tindakan transplantasi menjadi pilihan dalam penanganan pasien penyakit ginjal tahap akhir. Transplantasi ginjal dapat meningkatkan/memperbaiki kualitas hidup dan juga memangkas biaya perawatan yang besar dibandingkan dengan terapi dialisis. Trasplantasi ginjal merupakan tindakan pengambilan ginjal dari tubuh seseorang yang selanjutnya dicangkokan ke tubuh orang lain yang memiliki gangguan fungsi ginjal yang berat dan permanen.Transplantasi ginjal dapat memperbaiki fungsi ginjal yaitu fungsi filtrasi,fungsi ekskresi,fungsi hormonal yang seutuhnya sehingga lebih baik dari terapi pengganti ginjal lain (Alelign et al., 2018).

Keberlangsungan hidup pasien transplantasi ginjal sangat tergantung kepada fungsi ginjal yang telah ditranplantasikan tersebut. Salah satu pengukuran fungsi ginjal adalah dengan pemeriksaan Creatinine Reduction Ratio (CRR) pada hari ke-2 post transplantasi ginjal. CRR post transplantasi hari ke-2 berhubungan secara signifikan dengan fungsi ginjal selama satu tahun pertama. Ginjal transplan dinyatakan segera berfungsi (Immediate Graft Function (IGF)) bila dalam satu minggu pertama pasien tidak membutuhkan dialisis dan CRR pada hari ke-2 lebih dari 30\%. Sedangkan ginjal transplan dinyataan mengalami keterlambatan fungsi (Delayed Graft Function (DGF)) bila pada hari kedua sampai satu minggu pertama membutuhkan dialisis dan CRR pada hari ke-2 kurang dari 30\% (Rodrigo et al., 2007). Pasien dengan IGF memiliki fungsi renal dan graft survival yang lebih baik pada tahun pertama dibandingan dengan pasien DGF dengan dialisis (D DGF) maupun DGF tanpa dialisis (ND DGF) (Rodrigo et al., 2007). Pasien dengan nilai CCR pada hari kedua lebih dari 30\% (IGF) menunjukan fungsi renal dan graft survival yang lebih baik sampai tahun ke-5 post transplantasi, dan berbeda singnifikan dengan D DGF dan ND DGF (Vilar et al., 2010).

Beberapa faktor yang dapat mempengaruhi DGF diantaranya adalah tingkat missmatch Human Leukocyte Antigen (HLA). Tingginya tingkat missmatch HLA dapat meningkatkan kejadian penolakan graft pada tindakan transplantasi ginjal (Alelign et al., 2018; Kim et al., 2021), ketidakcocokan HLA donor dengan resipien juga menjadi faktor tidak berfungsinya ginjal post transplantasi (Farouk et al., 2020; Zachary \& Leffell, 2016). Serangkaiaa hasil penelitian menunjukan beberapa faktor yang dapat mempengaruhi IGF diantaranya adalah kompatibilitas HLA dan ABO, usia donor yang lebih muda, dan cold iskemia time yang lebih pendek (Sieńko et al., 2003), usia resipien, HLA AB dan DR mismatch, acut rejection (Pita-Fernández et al., 2010), dialisis yang lebih lama sebelum transplantasi dan (glomerular filtration rate) GFR donor yang rendah (Ho et al., 2018). Total Iskemic Time juga berkorelasi kuat dengan penurunan kadar kreatinin dan produksi urin pada pasien post transplantasi ginjal (Nugroho et al., 2019). Arrhythmia, left-ventricular ejection fraction (LVEF) under 56\%, HLA antibodies, penurunan fungsi kardiovaskuler donor and acute rejection merupakan faktor yang mempengaruhi kematian atau kegagalan fungsi graft pada tahun pertama pasien usia lebih 70 tahun post transplantasi ginjal (Lemoine et al., 2019).

Oleh karena itu penyelidikan terhadap faktor-faktor yang mempengaruhi berfungsinya graft dengan segera (IGF)) perlu dilakukan untuk meningkatkan manajemen pasien post tranplantasi ginjal yang lebih baik. Tujuan penelitian ini adalah mengidentifikasi faktor-faktor yang mempengaruhi IGF pada pasien tranplantasi ginjal donor hidup. 


\section{METODE}

Penelitian ini menggunakan desain studi kohort retrospektif pada pasien yang menjalani transplantasi ginjal di RSUP Dr. Kariadi Semarang dari tahun 2012 sampai 2020. Data demografi dan klinis diambil dari catatan laporan transplantasi ginjal RSUP dr Kariadi Semarang dan rekam medis pasien. Kriteria sampel didasarkan pada pencatatan yang lengkap terhadap variabel yang diteliti. Besar sampel pada penelitian ini adalah 44 responden.

Berdasarkan kelengkapan dokumen maka terdapat dua kelompok pengujian data, yaitu pengujian dengan besar sampel 44 dan pengujian dengan besar sampel 22. Pengujian terhadap besar sampel 22 responden didasarkan pada pemeriksaan resistive index (RI), yang baru dilakukan pengukuran sejak tahun 2018.

Hasil pengukuran adalah IGF dan DGF. Indikator IGF didasarkan pada nilai CRR yang diukur pada hari kedua post transplantasi ginjal. Dikatakan IGF bila nilai CRR hari kedua post transplantasi ginjal >30\%. Identifikasi faktor-faktor yang berhubungan IGF menggunakan analisis bivariat uji Chi-Square dengan tingkat kepercayaan 95\%. Sedangkan untuk mengetahui faktor yang paling berpengaruh menggunakan analisis regresi logistik ganda.

\section{HASIL}

Hasil penelitian (tabel 1) menunjukan bahwa dari 44 pasien post operasi tranplantasi ginjal pada hari kedua sebagian besar memiliki fungsi ginjal pada kategori IGF (nilai CRR > 30\%), yaitu sebanyak 29 orang (65,9\%). Hasil analisis faktor yang berhubungan dengan IGF $(n=44)$ menunjukan bahwa ada hubungan antara WIT terhadap IGF bermakna secara statistik ( $\rho$ value: 0.013, OR 9,000 (Cl: 1,534-52,796).

Hasil analisis regresi logistik ganda dengan Backward LR (tabel 2), diperoleh hasil bahwa WIT merupakan faktor yang paling berpengaruh secara statistik terhadap kadar CRR pada hari kedua post transplantasi ginjal, dengan $\rho$ value 0.013 dan OR 10,780 dan $\mathrm{Cl}$ lebih dari 1(1,65670,160). Hal tersebut menunjukan bahwa pasien transplantasi ginjal dengan WIT > 40 menit berisiko 10,780 kali kadar CRR $\leq 30 \%$ (DGF) pada hari kedua post transplantasi ginjal dibandingkan dengan WIT $\leq 40$ menit. Sementara usia resipien tidak berhubungan secara signifikan namun usia resipian tersebut dapat menjadi counfonding bagi variabel tersebut. Model regresi ini memiliki persamaan yang baik (good fit), dengan nilai $\rho$ value pada hosmer and lameshow test 0,745 dengan nilai Area Under the Curve (AUC) 74,5\% dan dengan akurasi 75\%.

Hasil analisis terhadap 22 responden yang memiliki hasil pengukuran Resistive Index (RI) lengkap, (tabel 3) diperoleh hasil sebagai berikut: dari seluruh responden yang memiliki nilai CRR $>30 \%$ seluruhnya memiliki nilai $\mathrm{RI} \leq 0,7$, dan responden yang memiliki nilai $C R R \leq 30 \%$, sebagian besar memiliki nilai RI >0,7. Hasil uji chi square diperoleh p value 0,002 dan OR 0,111 ( $\mathrm{Cl}$ : 0,030- 
$0,410)$ dan hasil regresi didapatan $\mathrm{p}$ value 0,006 dan $\mathrm{OR} 0,125(\mathrm{Cl}: 0,029-0,544)$ yang berarti nilai RI berpengaruh terhadap nilai CRR hari kedua post transpantasi ginjal bermakna secara statistik. Semakin rendah nilai RI maka semakin kecil peluang nilai CRR $\leq 30 \%$ (DGF). Dengan demikian pasien dengan nilai RI yang semakin kecil dapat mencegah retensi creatinin di dalam tubuh, atau semakin banyak creatinin yang akan dikeluarkan. 
Tabel 1. Hubungan antara Faktor Prediksi Early Graft Function (DGF: CRR $\leq 30 \%$; IGF: CRR $>30 \%)(n=44)$

\begin{tabular}{|c|c|c|c|c|c|}
\hline \multirow{2}{*}{ Variabel } & \multicolumn{2}{|c|}{ Creatinine Reductase Rasio } & \multirow{2}{*}{ OR } & \multirow{2}{*}{ IK 95\% } & \multirow{2}{*}{$P$} \\
\hline & $\leq 30 \%(n=15)$ & $>30 \%(n=29)$ & & & \\
\hline \multicolumn{6}{|l|}{ Usia resipien } \\
\hline$\leq 40$ tahun & $7(46,7)$ & $21(72,4)$ & 3,000 & $0,817-11,017$ & $0,092^{*}$ \\
\hline >40 tahun & $8(53,3)$ & $8(27,6)$ & & & \\
\hline \multicolumn{6}{|l|}{ Usia donor } \\
\hline$<60$ tahun & $9(60)$ & $20(69,0)$ & 1,481 & $0,404-5,428$ & $0,552^{*}$ \\
\hline$\geq 60$ tahun & $6(40)$ & $9(31,0)$ & & & \\
\hline \multicolumn{6}{|l|}{ Diabetes melitus } \\
\hline $\mathrm{Ya}$ & $3(20)$ & $2(6,9)$ & 3,250 & $0,479-22,068$ & $0,324^{\wedge}$ \\
\hline Tidak & $12(80)$ & $27(92,9)$ & & & \\
\hline \multicolumn{6}{|l|}{ Fraksi Ejeksi } \\
\hline$\leq 50 \%$ & $3(20)$ & $4(13,8)$ & 1,563 & $0,301-8,117$ & $0,675^{\wedge}$ \\
\hline$>50 \%$ & $12(80)$ & $25(86,2)$ & & & \\
\hline \multicolumn{6}{|l|}{ GFR Donor } \\
\hline$<40$ & $3(20)$ & $3(10,3)$ & 1,282 & $0,190-8,663$ & $1,000^{\wedge}$ \\
\hline$\geq 40$ & $12(80)$ & $26(89,7)$ & & & \\
\hline \multicolumn{6}{|l|}{ HLA matching } \\
\hline Mis match $>50 \%$ & $5(33,3)$ & $13(44,8)$ & 0,615 & $0,168-2,256$ & 0,462 \\
\hline Mis macth $\leq 50 \%$ & $10(66,7)$ & $16(55,2)$ & & & \\
\hline \multicolumn{6}{|l|}{ Cross-match } \\
\hline$>20 \%$ & $5(33,3)$ & $11(37,9)$ & 0,818 & $0,221-3,031$ & $0,764^{*}$ \\
\hline$\leq 20 \%$ & $10(66,7)$ & $18(62,1)$ & & & \\
\hline \multicolumn{6}{|l|}{ Jenis kelamin } \\
\hline Laki-laki & $11(73,3)$ & $19(65,5)$ & 0,691 & $0,174-2,738$ & $0,738^{\wedge}$ \\
\hline Perempuan & $4(26,7)$ & $10(34,5)$ & & & \\
\hline \multicolumn{6}{|l|}{ HLA-DR } \\
\hline Mis match o & $5(33,3)$ & $12(41,4)$ & 0,708 & $0,192-2,608$ & $0,603^{*}$ \\
\hline Mis match $\geq 1$ & $10(66,7)$ & $17(58,6)$ & & & \\
\hline \multicolumn{6}{|c|}{ Jumlah arteri donor } \\
\hline 1 & $9(60 \%)$ & $24(82,8)$ & 3,200 & $0,779-13,141$ & $0,098^{\prime}$ \\
\hline$>1$ & $6(40)$ & $5(17,2)$ & & & \\
\hline \multicolumn{6}{|l|}{ Protokol } \\
\hline High risk & $5(33,3)$ & $8(27,6)$ & 1,250 & $0,324-4,826$ & $0,746^{*}$ \\
\hline Low risk & $10(66,7)$ & $21(72,4)$ & & & \\
\hline
\end{tabular}


Tabel 2. Hubungan antara Faktor Prediksi Early Graft Function(DGF: CRR $\leq 30 \%$; IGF: CRR >30\%) $(n=44)$ (lanjutan).

\begin{tabular}{|c|c|c|c|c|c|}
\hline \multirow[t]{2}{*}{ Variabel } & \multicolumn{2}{|c|}{ Creatinine Reductase Rasio } & \multirow{2}{*}{ OR } & \multirow{2}{*}{ IK 95\% } & \multirow{2}{*}{$\mathbf{P}$} \\
\hline & $\leq 30 \%(n=15)$ & $>30 \%(n=28)$ & & & \\
\hline \multicolumn{6}{|c|}{ Warm ischemic time } \\
\hline$>40$ menit & $6(40)$ & $2(6,9)$ & 9,000 & $1,534-52,796$ & $0,013^{\wedge}$ \\
\hline$\leq 40$ menit & $9(60)$ & $27(93,1)$ & & & \\
\hline \multicolumn{6}{|l|}{ Nefroktomi } \\
\hline Kiri & $6(40 \%)$ & $11(37,9)$ & 0,917 & $0,256-3,286$ & $0,894^{*}$ \\
\hline Kanan & $9(60)$ & $18(62,1)$ & & & \\
\hline
\end{tabular}

Angka disajikan sebagai jumlah dan persentase; *uji Chi-Square; ^uji Fisher exact; OR: odds ratio; IK: interval kepercayaan

Tabel 2. Faktor-Faktor Prediksi Early Graft Function (DGF: CRR $\leq 30 \%$; IGF: CRR >30\%) (n=44)

\begin{tabular}{llccccc}
\hline & \multicolumn{1}{c}{ Variabel } & Kooefisien & $\rho$ value & OR & \multicolumn{2}{c}{$\mathrm{Cl}(95 \%)$} \\
\hline Step 1 & Jml arteri >1 (1) & 0.762 & 0.381 & 2.067 & 0.407 & 10.509 \\
& WIT $>$ 40 (1) & 2.225 & 0.023 & 9.253 & 1.360 & 62.940 \\
& usia resipien $>40$ & 1.271 & 0.092 & 3.566 & 0.812 & 15.668 \\
& Konstanta & -1.811 & 0.002 & 0.163 & & \\
\hline Step 2 & WIT >40 (1) & 2.378 & 0.013 & 10.780 & 1.656 & 70.160 \\
& usia resipien $>40$ & 1.311 & 0.079 & 3.710 & 0.860 & 16.014 \\
& Konstanta & -1.668 & 0.002 & 0.189 & & \\
\hline
\end{tabular}

Tabel 3. Hubungan antara Resistive Index dengan Early Graft Function (DGF: CRR $\leq 30 \%$; IGF: 


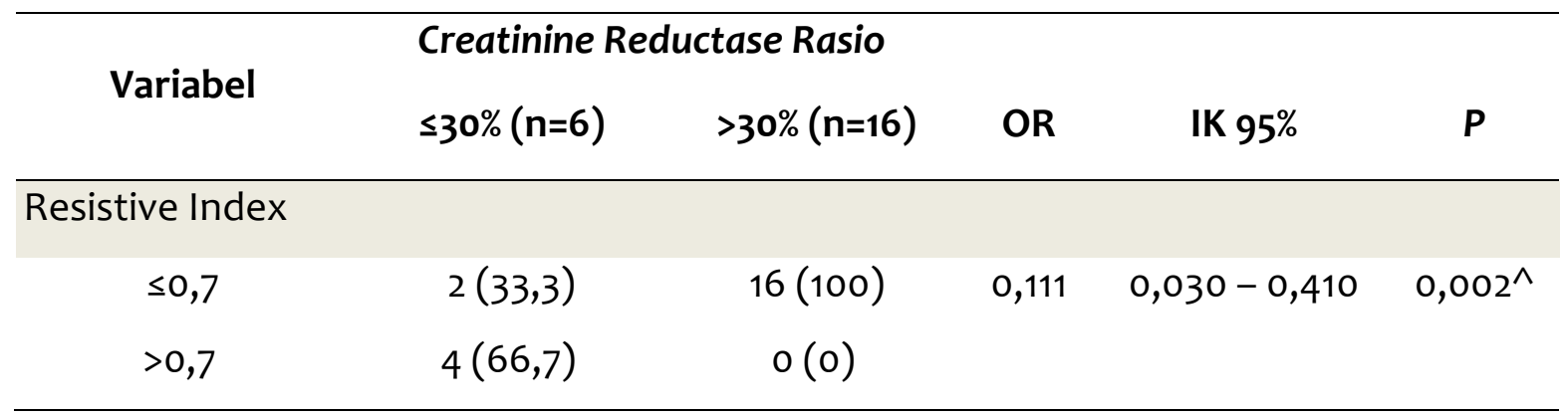

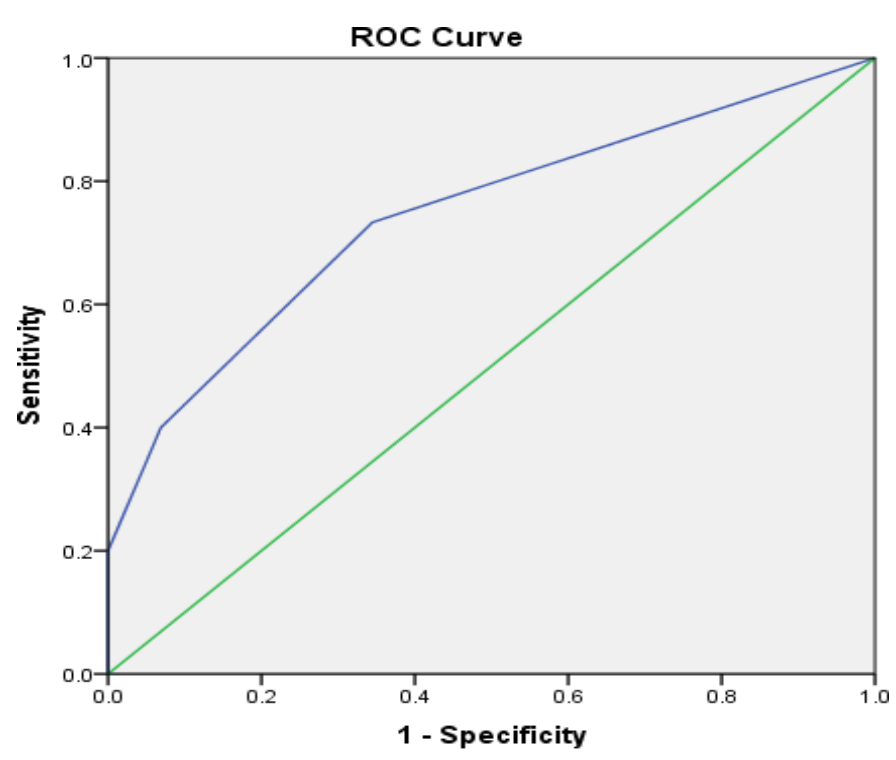

Diagonal segments are produced by ties.

Grafik 1. Area Under the Curve

\section{PEMBAHASAN}

Kajian terhadap penggunaan marker CRR hari kedua sebagai indikasi fungsi graft post traplantasi ginjal telah dilakukan seperti dalam penelitian Govani, et al ${ }^{14}$, Rodrigo, et al ${ }^{3}$ dan Vilar, et $a^{4}$. Hasil penelitian juga menunjukan bahwa CRR hari kedua post transplantasi ginjal berkorelasi signifikan dengan fungsi ginjal selama tahun pertama. Pasien dengan IGF memiliki fungsi ginjal yang secara signifikan lebih baik pada tahun pertama dan kelangsungan hidup cangkok yang lebih baik daripada pasien dengan D-DGF dan ND- DGF3. Dalam penelitian ini CRR hari kedua $\leq 30 \%$ sebagai indikasi adanya keterlambatan fungsi graft (delayed graft function/DGF) dan CRR hari kedua > 30\% mengindikasikan graft segera berfungsi (Immediate Graft Function/IGF).

Serangkaian hasil penelitian menunjukan beberapa faktor yang dapat mempengaruhi 
Hotmauli et al. J. Midwifery Health Sci. Sultan Agung. (2021) 1: (1)p25-33

https://doi.org/10.15294/jstrp.v1i1.44348

ISSN $2776-0685$

berfungsinya graft segera post transplantasi ginjal. Faktor tersebut diantaranya adalah human leukocyte antigen (HLA). Ketidakcocokan HLA donor dengan resipien juga menjadi faktor yang mempengaruhi tidak berfungsinya graft post transplantasi (Farouk et al., 2020; Zachary \& Leffell, 2016), kompatibilitas ABo, usia donor yang lebih muda, dan cold iskemia time yang lebih pendek (Sieńko et al., 2003); usia resipien, rejeksi akut (Pita-Fernández et al., 2010), dialisis yang lebih lama sebelum transplantasi dan GFR donor yang rendah (Ho et al., 2018). Arrhythmia, leftventricular ejection fraction (LVEF) under 56\%, HLA antibodies, penurunan fungsi kardiovaskuler donor and rejeksi akut merupakan factor yang mempengaruhi kematian atau kegagalan fungsi graft pada tahun pertama pasien usia lebih 70 tahun post transplantasi ginjal (Lemoine et al., 2019).

Pada penelitian ini dari analisis terhadap 44 sampel terhadap faktor usia resipien, usia donor, jenis kelamin, HLA, komorbid DM, jumlah ateri,crossmatch, nefrektomi dan warm ischemic time (WIT), didapatkan hasil faktor yang paling berpengaruh adalah WIT. Hasil penelitian ini menujukan bahwa faktor WIT merupakan faktor yang paling berpengaruh terhadap CRR hari kedua post transplantasi ginjal. WIT yang dimaksud pada penelitian ini merupakan lama waktu total WIT 1 dan WIT 2. WIT 1 adalah waktu dari mulai pembuluh darah ginjal donor diklem sehingga ginjal tidak mendapatkan aliran darah sampai preservasi ginjal dan WIT 2 adalah waktu ginjal diangkat dari tempat preservasi ginjal hingga akhirnya ginjal ditempelkan pada resipien dan mendapatkan aliran darah. Hasil penelitian menunjukan bahwa WIT >40 menit memberikan peluang nilai CRR hari kedua post transplantasi ginjal $\leq 30 \% 9$ kali lebih banyak dibandingan bila WIT $\leq 40$ menit. Artinya bila waktu yang digunakan untuk WIT $\leq 40$ menit maka pasien tersebut memiliki peluang besar untuk graft berfungsi dengan segera (IGF).

Hasil penelitian sebelumnya menunjukan bahwa WIT resipien maupun WIT donor tidak berhubungan dengan fungsi awal graft yang buruk (Khan et al., 2019); dan WIT tidak berhubungan dengan IGF (9). Hasil penelitian Toufeeq Khan, et al menunjukan bahwa open nephrectomy dapat mencegah atau meminimalkan terjadinya Poor Early Graft Function (PEGF). Responden pada penelitian Toufeeq Khan, et al semuanya adalah mendapatkan donor ginjal dari pendonor hidup dan hampir semuanya mengalami IGF (99,2\%). Hasil penelitian tersebut juga menunjukan bahwa WIT kurang dari 45 menit menyebabkan IGF dan WIT lebih dari 45 menit merupan faktor risiko terjadinya PEGF (Khan et al., 2019, 2020). Bila dicermati maka penelitian 
Hotmauli et al. J. Midwifery Health Sci. Sultan Agung. (2021) 1: (1)p25-33

https://doi.org/10.15294/jstrp.v1i1.44348

ISSN $2776-0685$

sebelumnya tersebut ada kesamaan dengan penelitian ini, yaitu semua responden mendapatkan donor ginjal dari pendonor hidup, sebagain besar responden mengalami IGF $(65,9 \%)$ dan WIT > 40 menit merupakan factor risiko untuk terjadinya DGF. Dengan demikian hasil penelitian Toufeeq Khan, et al sejalan dengan penelitian ini.

Hasil penelitian ini juga sejalan dengan penelitian Tennankore, et al yang menunjukan bahwa WIT yang berkepanjangan berkorelasi dengan luaran jangka panjang yang merugikan dan kelangsungan hidup graft pada pasien setelah transplantasi ginjal yang lebih buruk. Pada penelitian Tennankore, et al dilakukan terhadap 131.677 penerima transplantasi ginjal, menemukan bahwa WIT yang lebih lama dari 30 menit dikaitkan dengan bahaya relatif yang lebih tinggi untuk kejadian kematian atau kegagalan graft atau keduanya (Ferede et al., 2020). Sementara pada penelitian ini dikatakan fungsi graft dalam katagori IGF bila WIT $\leq 40$ menit. Hasil penelitian Kaminska, et al dan Ferede, et al juga mendukung hasil penelitian ini. Hasil penelitian Kaminska, et al menunjukan bahwa memperpendek waktu WIT memberikan dampak positif secara eksklusif sejak dini dan secara signifikan meningkatkan fungsi graft dengan segera, mencegah DGF dan mencegah rejeksi graft (Kamińska et al., 2016). Hasil penelitian Ferede, et al melaporkan bahwa WIT 2 yang berkepanjangan adalah prediktor independen untuk DGF baik dalam transplantasi ginjal donor hidup maupun donor jenazah, walaupun WIT 2 tampaknya tidak mempengaruhi hasil graft jangka pendek pada 3 bulan pasca transplantasi. Artinya, tidak ditemukan ada perbedaan yang signifikan dalam kadar kreatinin serum pada 1 dan 3 bulan pertama post transplantasi ginjal (Ferede et al., 2020). Penelitian Ferede, et al dapat dikatakan sejalan dengan hasil penelitian ini, mengingat parameter IGF dilihat dari CRR yang dinilai pada hari kedua post transplantasi ginjal.

Panjangnya waktu WIT merupakan faktor yang dapat dimodifikasi pada transplantasi ginjal. Faktor ini dapat diperpendek untuk dapat meningkatkan berfungsinya graft dengan segera setelah transplantasi ginjal. Beberapa penelitian sebelumnya menunjukan bahwa WIT tidak berkorelasi dengan fungsi graft segera setelah transplantasi ginjal namun hasil penelitian ini dan beberapa penelitian lainnya menunjukan WIT merupakan faktor prediksi fungsi graft segera setelah transplantasi ginjal. WIT yang lebih pendek memungkinkan tubular berfungsi lebih baik, mencegah kerusakan dan juga kematian sel tersebut. Beberapa penulis telah melaporkan bahwa WIT yang lebih pendek dikaitkan dengan penurunan insiden nekrosis tubular akut setelah 
Hotmauli et al. J. Midwifery Health Sci. Sultan Agung. (2021) 1: (1)p25-33

https://doi.org/10.15294/jstrp.v1i1.44348

ISSN $2776-0685$

transplantasi ginjal (Kamińska et al., 2016). Hasil penelitian Heylen, et al melaporkan efek lama anastomosis pembuluh darah pada hasil allograft 669 transplantasi ginjal. WIT secara independen meningkatkan risiko fungsi graft yang tertunda dan fungsi graft yang terganggu setelah transplantasi. WIT berkepanjangan dikaitkan dengan peningkatan risiko fibrosis interstitial dan atrofi tubular (Heylen et al., 2015).

Selain WIT yang harus diperhatikan dalam transplantasi ginjal, variable usia resipien. Hal tersebut dikarenakan dari hasil pemodelan regresi pada penelitian ini bisa jadi variable tersebut dapat mengganggu variable dependent. Walaupun mereka bukan merupakan variable yang paling mempengaruhi EGF. Resistrive Index (RI) dalam pengujian dengan besar sampel 22 responden, merupakan variable yang berpengaruh juga terhadap IGF pada pasien post transplantasi ginjal di RSUP DR. Karyadi Semarang. Adapun OR yang diperoleh adalah kurang dari 1. Artinya dengan nilai $\mathrm{RI} \leq 0,7$ dapat mencegah terjadinya DGF, dengan kata lain nilai RI yang semakin baik merupakan faktor prediksi untuk peluang terjadinya IGF yang semakin besar. RI merupakan ukuran aliran darah pulsatil yang mencerminkan resistensi terhadap aliran darah. Resistensi aliran darah yang tinggi menyebabkan tekanan darah yang tinggi dan perfusi menjadi tidak adekuat. Kerusakan berat vasa renal pada penyakit ginjal kronik mengakibatkan penurunan perfusi dan ditunjukkan oleh meningkatnya angka RI. Pengukuran RI memberikan evaluasi real time terhadap struktur graft dan vaskularisasinya. Dengan RI yang semakin rendah dapat mengindikasikan vaskularisasi graft yang semakin baik, sehingga dapat meningkatkan fungsi graft dan keberlangsungan hidup graft tersebut.

Pengukuran RI awal setelah transplantasi ginjal dengan menggunakan ultrasonografi telah diteliti sebelumnya. Enhesari, et al dalam penelitiannya mengemukakan bahwa parameter ultrasonografi, yaitu RI, Pulsatility Index (PI), dan Diastolic Velocity (DV) yang dilakukan pemeriksaan pada awal post transplantasi ginjal berpengaruh terhadap berfungsinya graft yang lebih baik pada 6 bulan pertama post transplantasi (Enhesari et al., 2014). Menurut penulis penelitian tersebut mendukung hasil penelitian ini, walaupun ada berbedaan indikator berfungsinya graft. Pada penelitian tersebut menggunakan parameter GFR, sedangkan pada penelitian ini mengunakan CRR hari kedua post transplantasi.

Hasil penelitian ini juga sejalan dengan hasil penelitian Mocny, et al yang menunjukan bahwa nilai $\mathrm{RI} \geq 0,9$ hari pertama post transplantasi atau peningkatan nilai $\mathrm{PI} \geq 1,9$ akan meningkatkan risiko 
Hotmauli et al. J. Midwifery Health Sci. Sultan Agung. (2021) 1: (1)p25-33

https://doi.org/10.15294/jstrp.v1i1.44348

ISSN $2776-0685$

DGF sebesar 19 kali. Rata- rata nilai RI pada group DGF 0.9 lebih tinggi dari rata-rata nilai RI pada group IGF 0.74 (Mocny et al., 2016). Ada perbedaan nilai RI yang digunakan pada penelitian sebelumnya dengan penelitian ini. Pada penelitian sebelumnya nilai RI yang berisiko terjadinya DGF adalah $\geq 0,9$, sementara pada penelitian ini nilai RI sebagai prediktor terjadinya IGF adalah $\leq 0,7$ dan sebagai risiko terjadinya DGF adalah >0,7. Studi sebelumnya melaporkan bahwa RI tinggi yang diukur setidaknya 3 bulan setelah operasi dikaitkan dengan fungsi graft yang buruk dan kematian. Pasien dengan RI>0,8 terjadi pencapaian penurunan 50 \% kadar kreatinin lebih lambat, kegagalan allograft atau kematian pada tingkat yang secara signifikan lebih tinggi daripada mereka yang memiliki nilai RI yang lebih rendah. Selain itu, RI tinggi juga berkorelasi dengan nefropati allograft kronis (Tirtayasa et al., 2019). Sebuah studi yang dilakukan Rodrigo et al, menemukan bahwa nilai RI tidak mempengaruhi luaran hasil graft dalam jangka panjang. Mereka menemukan bahwa kelangsungan hidup cangkok 1 tahun lebih buruk pada pasien dengan nilai RI tinggi, namun, tingkat kelangsungan hidup cangkok 3 dan 5 tahun tidak lebih buruk antara pasien RI tinggi dan rendah. Selain itu, mereka menjelaskan bahwa efek akut DGF terhadap edema interstitial dan RI dapat menghilang seiring berjalannya waktu (Rodrigo et al., 2007). Sedangkan studi meta analisis yang dilakukan oleh Tirtayasa, et al dari lima studi mengenai hubungan antara pengukuran awal RI dan kelangsungan hidup graft jangka panjang telah menunjukkan bahwa pasien dengan RI rendah dalam pengukuran awal lebih memiliki tingkat kelangsungan hidup graft jangka panjang yang lebih tinggi daripada mereka yang memiliki RI tinggi. Begitu juga hubungan antara pengukuran RI post transplantasi ginjal dengan berfungsinya graf dengan segera. Mereka mengemukakan bahwa pasien dengan nilai RI yang rendah berpeluang untuk mengalami IGF daripada pasien dengan nilai RI tinggi (Tirtayasa et al., 2019).

Studi meta analisis yang dilakukan oleh Bellos, Perrea dan Kontzoglou juga menunjukan bahwa nilai RI yang dievaluasi segera setelah transplantasi ginjal dan nilai RI tersebut menunjukan nilai yang tinggi berhubungan secara signifikan terhadap kejadian DGF yang tinggi pula (Bellos et al., 2019). Pada penelitian tersebut nilai RI ditentukan dengan rumus sebagai berikut: (peak systolic velocity - end-diastolic velocity)/peak systolic velocity, diukur secara transparan pada tingkat arteri arkuata atau interlobar, di bawah panduan Color Doppler. Tiga bentuk gelombang pada segmen ginjal superior, median, dan bawah diperoleh dan selanjutnya RI diperkirakan sebagai rata-rata 
Hotmauli et al. J. Midwifery Health Sci. Sultan Agung. (2021)!: (1)p25-33

https://doi.org/10.15294/jstrp.vi11.44348

ISSN 2776-0685

pengukuran di atas . Sedangkan DGF terdeteksi ketika kebutuhan untuk dialisis diperlukan dalam minggu pertama post transplantasi (Bellos et al., 2019). Walaupun batasan nilai RI rendah dan tinggi dengan penelitian sebelumnya ada beberapa perbedaan, namun dapat disimpulkan bahwa penelitian sebelumnya sejalan dengan hasil penelitian ini, semakin tinggi nilai RI semakin berpeluang untuk terjadinya DGF. Nilai WIT dan RI dapat memprediksi IGF pada pasien post transplantasi ginjal dengan parameter CRR hari ke dua post transplantasi ginjal. Penelitian ini memiliki beberapa keterbatasan diantaranya adalah besar sample yang masih lebih kecil dibandingkan penelitian- penelitian sebelumnya.

\section{KESIMPULAN}

Nilai WIT dan RI yang diukur segera setelah transplantasi ginjal berhubungan dan dapat memprediksi kejadian IGF, dengan parameter didasarkan pada nilai CRR yang diukur hari kedua post transplantasi bermakna secara statistic. Pada penelitian selanjutnya dapat dilakukan penelitian pengaruh RI dan WIT terhadap segera bergungsinya graft dan keberlangsungan hidup graft untuk jangka waktu yang lebih lama dengan sampel yang lebih besar. Hasil ini dapat digunakan sebagai salah satu literature yang dapat digunakan untuk perbaikan kualitas manajemen transplantasi ginjal.

\section{DAFTAR PUSTAKA}

Alelign, T., Ahmed, M. M., Bobosha, K., Tadesse, Y., Howe, R., \& Petros, B. (2018). Kidney Transplantation: The Challenge of Human Leukocyte Antigen and Its Therapeutic Strategies. $J$ Immunol Res.

Bellos, I., Perrea, D. N., \& Kontzoglou, K. (2019). Renal resistive index as a predictive factor of delayed graft function: A meta-analysis. Transplant Rev (Orlando), 33(3), 145-153.

Enhesari, A., Mardpour, S., Makki, Z., \& Mardpour, S. (2014). Early ultrasound assessment of renal transplantation as the valuable biomarker of long lasting graft survival: a cross-sectional study. Iran J Radiol, 11(1).

Farouk, S., Zhang, Z., \& Menon, M. C. (2020). Non-HLA donor-recipient mismatches in kidney transplantation-A stone left unturned. Am J Transplant, 20(1), 19-24.

Ferede, A. A., Walsh, A. L., Davis, N. F., Smyth, G., Mohan, P., Power, R., Forde, J., O’Kelly, P., \& Llittle, D. (2020). Warm Ischemia Time at Vascular Anastomosis is an Independent Predictor for Delayed Graft Function in Kidney Transplant Recipients. Exp Clin Transplant, 18(1), 13-18.

Heylen, L., Naesens, M., Jochmans, I., Monbaliu, D., Lerut, E., Claes, K., Heye, S., Verhamme, P., Coosemans, W., Bammens, B., Evenepoel, P., Meijers, B., Kuypers, D., Sprangers, B., \& Pirenne, J. (2015). The effect of anastomosis time on outcome in recipients of kidneys donated after brain death: a cohort study. Am J Transplant, 15(11), 2900-2907. 
Ho, C. H., Lan, C. W., Liao, C. Y., Hung, S. C., Li, H. Y., \& Sung, Y. J. (2018). Mesenchymal stem cells and their conditioned medium can enhance the repair of uterine defects in a rat model. Journal of the Chinese Medical Association, 81(3), 268-276. https://doi.org/10.1016/j.jcma.2017.03.013

Kamińska, D., Kościelska-Kasprzak, K., Chudoba, P., Hałoń, A., Mazanowska, O., Gomółkiewicz, A., Dzięgiel, P., Drulis-Fajdasz, D., Myszka, M., Lepiesza, A., Polak, W., Boratyńska, M., \& Klinger, M. (2016). The influence of warm ischemia elimination on kidney injury during transplantation - clinical and molecular study. Sci Rep, 6.

kemenkes RI. (2013). Riset kesehatan dasar (K. K. R. Indonesia (ed.)).

Khan, T. F. T., Ahmad, N., Serageldeen, A. S., \& Fourtounas, K. (2019). Implantation Warm Ischemia Time in Kidney Transplant Recipients: Defining Its Limits and Impact on Early Graft Function. Ann Transplant, 24, 432-438.

Khan, T. F. T., Mirza, I., Rashid, T., \& Anwar, N. (2020). Unrelated donors in kidney transplantation: Myths and the gruesome reality. Saudi Journal of Kidney Desease and Transplantation, 31(2), 563-567.

Kim, J. J., Fuggle, S. V, \& Marks, S. D. (2021). Does HLA matching matter in the modern era of renal transplantation? Pediatr Nephrol, 36(1), 31-40.

Lemoine, M., Beauport, D. T., Lobbedez, T., Choukroun, G., Ligny, B. H. de, Hazzan, M., Guerrot, D., \& Bertrand, D. (2019). Risk Factors for Early Graft Failure and Death After Kidney Transplantation in Recipients Older Than 70 Years. Kidney Int Rep, 4(5), 656-666.

Mocny, G., Bachul, P., Chang, E.-S., \& Kulig, P. (2016). The value of Doppler ultrasound in predicting delayed graft function occurrence after kidney transplantation. Folia Med Cracov, 56(4), 51-62.

Nugroho, E. A., Hidayat, A., \& Hidayat, A. T. (2019). Correlation Between Total Ischemic Time with Creatinin Level and Urine Production in Kidney Transplant: A Single Centre Report. Novel Research in Sciences, 1(1).

Pita-Fernández, S., Valdés-Cañedo, F., Seoane-Pillado, T., Lorenzo-Aguiar, D., Oliver-Garcia, J., Blanco-Castro, N., Seijo-Bestilleiro, R., \& Pértega-Díaz, S. (2010). Influence of early graft function after renal transplantation and its impact on long-term graft and patient survival. Transplant Proc, 42(8), 2856-2858.

Rodrigo, E., Ruiz, J. C., Piñera, C., Fernández-Fresnedo, G., Escallada, R., Palomar, R., Cotorruelo, J. G., Zubimendi, J. A., Francisco, A. L. M. de, \& Arias, M. (2007). Creatinine reduction ratio on post-transplant day two as criterion in defining delayed graft function. Am J Transplant, 4(7), 1163-1169.

Sieńko, J., Wiśniewska, M., Ostrowski, M., Ciechanowski, K., Safranow, K., Chudyk, A., Fronczyk, A., Rózański, J., Kamiński, M., Sulikowski, T., Romanowski, M., Pabisiak, K., Paczkowski, M., \& Mizerski, A. (2003). Factors that impact on immediate graft function in patients after renal transplantation. Transplant Proc, 35(6), 2153-2154.

Tirtayasa, P. M. W., Duarsa, G. W. K., Situmorang, G. R., Yudiana, I. W., Santosa, K. B., Oka, A. A. G., Rodjani, A., \& Rasyid, N. (2019). Association between Early Resistive Index Measurement and Early Graft Function and Long-Term Graft Survival after Kidney Transplantation: an Evidence-based Clinical Review. Acta Med Indones, 51(1), 77-85.

Vilar, E., Varagunam, M., Yaqoob, M. M., Raftery, M., \& Thuraisingham, R. (2010). Creatinine reduction ratio: a useful marker to identify medium and high-risk renal transplants. Transplantation, 89(1), 97-103. 
Hotmauli et al. J. Midwifery Health Sci. Sultan Agung. (2021)!:(1)p25-33

https://doi.org/10.15294/istrp.v111.44348

ISSN 2776-0685

Zachary, A. A., \& Leffell, M. S. (2016). HLA Mismatching Strategies for Solid Organ Transplantation - A Balancing Act. Front Immunol, 7(575). 